Article

\title{
Modern Wheat Varieties as a Driver of the Degradation of Spanish Rainfed Mediterranean Agroecosystems throughout the 20th Century
}

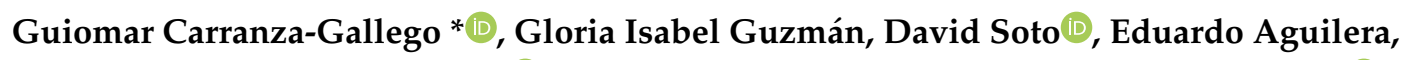

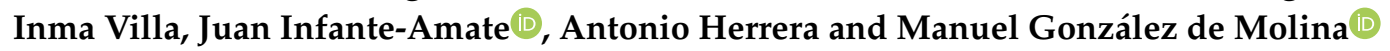 \\ Agroecosystem History Laboratory, University Pablo de Olavide, 41013 Seville, Spain; giguzcas@upo.es (G.I.G.); \\ dsotfer@upo.es (D.S.); emagufer@upo.es (E.A.); ivilgil@upo.es (I.V.); jinfama@upo.es (J.I.-A.); \\ ahergon@upo.es (A.H.); mgonnav@upo.es (M.G.d.M.) \\ * Correspondence: gcargal@upo.es
}

Received: 26 September 2018; Accepted: 13 October 2018; Published: 16 October 2018

check for updates

\begin{abstract}
The high grain yield of modern varieties (MV) respond to the increase in fossil-based inputs, and the widespread belief that they are more productive than old varieties $(\mathrm{OV})$ is biased. This belief focuses only on marketable biomass, without considering the consequences on agroecosystem sustainability of the reductions in other portions of NPP. Additionally, field comparisons of OV and MV were normally conducted under industrialized farming conditions, which is detrimental for OV performance. Both trials carried out in this study comparing wheat OV and MV show that, under Mediterranean rainfed conditions and traditional organic management, aerial and belowground biomass production of $\mathrm{OV}$ is higher than that of $\mathrm{MV}$, without significantly decreasing yield and enabling a better competition against weeds. From the data of our trials, bibliographic review and information from historical sources, we have reconstructed the NPP and destinations of biomass of Spanish wheat fields (1900-2000). Varietal replacement entailed the reduction in residues and unharvested biomass (UhB), which involved soil degradation in rainfed cereal fields and undermining heterotrophic trophic webs. Our results suggest that OV can increase the sustainability of rainfed Mediterranean agroecosystems at present through the improvement of soil quality, the reduction of herbicides use, and the recovery of biodiversity.
\end{abstract}

Keywords: varietal change; landraces; biomass partitioning; NPP; roots

\section{Introduction}

The replacement of old varieties (OV) by modern (MV) ones was inextricably linked to the agrarian industrialization process, and can be considered the cornerstone of the Green Revolution, because new varieties were specifically designed to respond with yield increases to the incorporation of inputs of fossil origin [1-3].

The varietal change was especially intense in cereals. The high proportion of global cropland area dedicated to these crops and their relevance in human diet placed them at the center of breeding programs by the experimental stations that led the Green Revolution. With regards to wheat, the effect of varietal replacement on grain yield has been outstanding [4] and has led to the widespread belief that MV are more productive than OV [5-8].

However, this statement must be put into context. In the first place, because it assumes one part (the grain) to be the whole (net primary production); Secondly, because most of the comparative tests between types of varieties are carried out under conditions of industrialized agriculture.

The conception of the marketable biomass (mainly grain) as the only important one is reductionist and has entailed the abandonment of the functions that the rest of the biomass plays in the 
agroecosystems. It is well known that the sustainable management of an agroecosystem depends on the levels of biodiversity and soil organic matter (SOM), the appropriate replenishment of soil fertility, and the possibilities of closing biogeochemical cycles on a local scale, among other factors [9]. This implies that a significant part of the biomass generated must recirculate to perform the basic productive and reproductive functions of the agroecosystem: seeds, animal labor, soil organic matter, biodiversity, and so forth. In other words, in order to be sustainable, the agroecosystem functioning must be based on internal loops of biomass with low dependence on the external incorporation of energy. High density of internal biomass loops (and, therefore, of energy) maintains an adequate quality of the agroecosystem with low entropic costs and, consequently, maintaining the long-term social extraction of biomass and the provision of ecosystem services [10-13] (pp. 41, 45).

In short, the maintenance of internal loops in agroecosystems is directly related to the use of a significant part of net primary production to fuel them. This has major implications when it comes to calculating net primary productivity (NPP), which must then be broken down into different categories according to its productive or reproductive functionality [10].

Regarding wheat, there is a broad consensus that the grain yield increase of the Green Revolution cultivars is explained by the increase in Harvest Index (HI) and not by the increase in aerial biomass with respect to OV, the latter remaining stable $[5,6,14,15]$. Therefore, the increase of biomass for human society has been done at the expense of biomass that fed other chains of heterotrophic organisms and that allowed both the accumulation of edaphic organic matter and the recycling of nutrients. However, these studies frequently do not account for all the NPP and do not consider the root and weed biomass. In accounting for these, the hypothesis that varietal substitution has been a direct cause of the deterioration of agroecosystems, and not only the use of inputs from fossil origin associated with MV, could be reinforced or discarded.

On the other hand, most field experiments comparing old and modern wheat varieties are carried out under conditions of industrialized agriculture $[5-8,14,15]$. This situation introduces a strong bias in the comparison, since OV were selected under very different management conditions. Therefore, it is convenient and necessary to explore the potential of OV biomass production in their proper context. That is, applying an Experimental History approach that recreates the traditional organic management in which these varieties were selected. The information obtained would have two obvious uses. The first one, for those researchers (ecologists, agrarian historians, etc.) that need to estimate the NPP of traditional agroecosystems from historical sources, these sources usually only provide information of the harvested biomass. In this case, the calculation of the NPP should be based on adequate partitioning indices for OV under traditional management. In the second place, agroecologists, agronomists, etc. involved in the design and evaluation of sustainable agroecosystems need to assess whether the biomass that is not extracted from the agroecosystems is enough to maintain the quality of the agroecosystem fund elements (soil, biodiversity, etc.). In this sense, an appropriate varietal choice must respond not only to productivity criteria, but also to sustainability.

Conversely, the performance and partitioning indices of MV under modern management are better documented in the scientific literature, and it is not essential to carry out additional trials.

Our hypothesis is that, under conditions of traditional organic agriculture, $\mathrm{OV}$ are equal or more productive than MV, whether considering the grain or the NPP. However, they would have lower HI than MV, both under organic traditional management and under conventional practices. Both aspects, higher NPP and lower HI, would have enabled OV to recycle larger quantities of biomass in the agroecosystem in the past and, with it, the maintenance of the quality of the agroecosystems fund elements, with respect to MV in the present.

To test our hypothesis, we have focused on rainfed wheat under Mediterranean agro-climatic conditions. Wheat are fundamental crops in the Mediterranean culture consist of the Mediterranean Trinity: wheat, vine, and olive. The first complete statistical analysis of agrarian production in Spain shows that wheat occupied 4.2 Mha in 1922, and was $94 \%$ cultivated under rainfed conditions $(22 \%$ of the cropland approx.) [16]. Currently, it occupies $2.2 \mathrm{Mha}$, and is $86 \%$ under rainfed conditions $(14 \%$ of 
the cropland approx.) [17], reaching $25 \%$ of the harvested area of the coastal Mediterranean countries (excluding France) [4]. This remarkable occupation of the territory confers to wheat varietal change a great capacity to modify Mediterranean agroecosystems.

The Mediterranean climate is characterized by mild, wet winters and hot, dry summers, and it is localized in five areas around the world. Most of its subtypes can be classified as semi-arid, and rainfed crops are usually exposed to water deficit conditions. Cropland soils in Mediterranean areas have low soil organic matter contents due to climate limitations to NPP. The water deficit and the low soil organic carbon content (SOC) make Mediterranean agriculture very vulnerable, both to the cyclic drought events and to the current process of global climate change. The low NPP also hinders the balance between alternative uses: human consumption, maintenance of the soil quality, livestock feeding, and wild fauna feeding. This fragile balance could be substantially modified due to changes in the morphology and physiology of cereals promoted by the Green Revolution, altering the quality of the fund elements of Mediterranean agroecosystems.

In particular, our objectives have been the following: (a) to quantify the NPP of old and modern wheat cultivars, under two representative traditional organic management types; (b) to quantify biomass allocation in wheat plant and within cultivated plots (grain, straw, husk, roots and weed biomass) under these management conditions, as well as the related partitioning indices; $c$ ) to define the biomass partitioning indices of MV under industrialized management in Spain, through a bibliographic review; (d) to apply the biomass partitioning indices obtained by both routes to the estimate of the NPP of wheat fields in Spain throughout the 20th century; (e) to model the biomass flows according to their destination in the same period of time; (f) to discuss to what extent the alteration of the production and end-uses of the biomass has been able to alter the fund elements (soil, biodiversity) quality in these agroecosystems.

\section{Materials and Methods}

\subsection{Data Collection}

The selection and definition of the main traditional organic management of wheat in the early 20th century in Spain has been based on the review of historical sources [18]. The selected organic managements are those applied to rainfed wheat under contrasting soil quality conditions. In most fertile soils, wheat was planted in rotation with a legume and amended with manure. At the other end of the typical soil quality range, in lower quality lands, wheat was cultivated in "one third rotation" (wheat-fallow-fallow), without application of manure. Under intermediate intensity management (e.g., wheat-fallow, wheat-legume-fallow...) the behavior of wheat varieties should be also understood as intermediate between both extremes. Table 1 summarizes tasks performed in trials under both selected managements. From these trials we have averaged the biomass partitioning indices of OV under traditional management.

We have reconstructed the evolution of yield and harvested straw from the construction of eleven points in time between 1900 and 2000, using 5-year averages to buffer year-to-year variability. Sources used in our study are the statistics provided by the Spanish government, with different quality and frequency from 1900 to 2000 [16-21]. The statistical information refers to fresh matter.

$\mathrm{HI}$ and aerial weed biomass of MV under modern management come from a bibliographic review of scientific literature. Data selected come from field experiments under rainfed Mediterranean agroclimatic conditions (see Tables S1 and S2, Supplementary Materials). Aerial weed biomass values found in this revision show a high dispersion, which gives rise to a high standard deviation of the mean. Therefore, a sensitivity analysis with a weed-free scenario was performed.

Direct estimates of root biomass comparing OV and MV are very scarce. The few studies found indicate that wheat OV has a more developed root system and increases the root—shoot (R:S) ratio with respect to MV [22-24]. On the other hand, there are many other factors (edapho-climatic, management, etc.) that affect the ratio between root and aerial biomass [25]. This means that shoots and roots respond 
differently to changes in environmental conditions. For example, in areas with a Mediterranean climate, the R:S ratio is usually larger than in areas of higher precipitation, due to the need to spread roots over a larger soil volume to capture enough water [26].

On the other hand, organic management seems to favor root development compared to industrialized management [27]. In general, this ratio decreases with management changes that promote yield, including synthetic nutrient inputs [27-29] and irrigation [30]. Consequently, using a fixed amount of root mass ("Fixed root mass") may lead to better fit with experimental data than a using a fixed R:S ratio $[27,29,31]$. However, Wiesmeier et al. [32] suggest that the R:S ratios of crops may have even increased in recent history. Given this controversy, we have built a R:S ratio throughout the 20th century that tempers the impact of changes in aerial biomass on root biomass that reflects the percentage differences in this index between OV and MV and organic and industrialized management (Table S5). For 1900-1933, the root: shoot ratio (0.36) comes from our own trial. This ratio has been multiplied by aerial biomass of wheat for those years (calculated from the grain yield from historical sources already mentioned and HI from our experimental field), to obtain root biomass. In 1940-50, the ratio applied was greater, to temper the fall in aerial biomass caused by the Spanish Civil War (1936-39), since under conditions of lower productivity root biomass remains more stable. For MV in 2000, the R:S ratio comes from data provided by recent trials conducted in Spain under rainfed conditions [33-35]. This ratio has been multiplied by wheat aerial biomass for that year to obtain root biomass. Ratios for 1980 and 1990 have been modulated so that root biomass maintained similar values to the year 2000. The period between 1960-70 has been considered as a transitional period, and the R:S ratio has been calculated considering that the varietal substitution was 50\% for 1960 and $75 \%$ for 1970 .

Weed root biomass has not been considered in this study because it lacks minimally reliable data on which to base it. In the absence of trials in which this variable has been measured, regardless of the agroclimatic conditions, it must be added that the weeds complex present in plots cultivated with OV under organic management is different from that of MV under industrialized management [36] and, therefore, it is not possible to attribute the same R:S ratio for weeds in this study.

Lastly, indices applied to calculate wheat biomass destinations (human, animal, unharvested biomass) throughout the 20th century come from FAOSTAT [4] and the Spanish statistical yearbooks [17]. FAOSTAT [4] offers annual data on grain destinations since 1961, while the Spanish yearbooks [17] offer straw harvest data. In the case of grain, for previous times we have assumed the same percentages as for 1960, since the industrialization of Spanish agriculture was just beginning. The share of straw burned comes from Soto et al. [37] (Table S3).

\subsection{Trials: Site Description and Experimental Design}

Two field experiments were carried out at two locations in Southern Iberian Peninsula, Sierra de Yeguas $\left(37^{\circ} 07^{\prime} 26^{\prime \prime} \mathrm{N} 4^{\circ} 52^{\prime} 07^{\prime \prime} \mathrm{W}\right)$ and Ronda ( $\left.36^{\circ} 44^{\prime} 14^{\prime \prime} \mathrm{N} 5^{\circ} 09^{\prime} 53^{\prime \prime} \mathrm{W}\right)$ (Málaga province). Both farmlands had been under organic management for the previous 15 years. To cover for interannual variability, the field experiments were carried out during three consecutive growing seasons (2013-2016). The main soil properties of the experimental sites are shown in Table S4. Annual precipitation was $56.4 \%$ and $81.9 \%$ of the mean value, for Sierra de Yeguas and Ronda, respectively (Table 1). The same old (Rubio, Recio, Sierra Nevada, Barbilla Roja, Rojo Pelon, Blanco Verdial) and modern (Avispa, Simeto, Vitron, García, Marius, Artur Nick) durum and bread wheat varieties were sown at both locations. OV were landraces grown during the first third of the 20th century in the region. Their seeds came from the Phytogenetic Resource Centre of the National Agrarian Research Institute of Spain (CRF-INIA). MV were chosen among lately released, currently used varieties, considering their good reputation among farmers in the area. 
Table 1. Annual rainfall and management practices of the field experiments.

\begin{tabular}{ccc}
\hline & $\begin{array}{c}\text { Sierra de Yeguas } \\
\text { (Wheat-Faba Bean Rotation) }\end{array}$ & Ronda (One-Third Rotation) \\
\hline Rainfall $(\mathrm{mm})$ & & \\
2013-2014 & 433 & 612 \\
$2014-2015$ & 344 & 448 \\
2015-2016 & 363 & 846 \\
1982-2012 average & 673 & 775 \\
Rotation & Wheat-faba bean & Wheat-fallow-fallow \\
Fertilization & Manure & - \\
Weed control & $(3.6 \%$ N, d.m.) $(3.0$ Mg ha & , f.m.) \\
Irrigation & Manual weeding & - \\
& Rainfed & Rainfed \\
\hline
\end{tabular}

The farmland at Sierra de Yeguas was cultivated with a two-year crop rotation called ruedos, consisting of wheat and faba bean (Vicia faba). Both species were grown in adjacent plots, interchanging cultivation plots each year. Before wheat seeding in the first year of the rotation, $3 \mathrm{tha}^{-1}$ of manure was applied, but none to the faba bean crop. Weeds were controlled by hand. The farmland at Ronda was cultivated with a wheat-fallow-fallow rotation (one-third rotation). No weed control or fertilization were applied to the soil.

Both fields were planted between October 29 and November 19. Sowing rate was $200 \mathrm{~kg} \mathrm{ha}^{-1}$ for wheat and $110 \mathrm{~kg} \mathrm{ha}^{-1}$ for faba bean. Harvest took place between May 21 and June 23. Wheat and faba bean were seeded and harvested at the same time. Each trial consisted of a completely randomized block design with four blocks separated by a non-seeded stripe $1 \mathrm{~m}$ in width. Plots were $6 \times 4 \mathrm{~m}$ size.

\subsection{Sampling Method}

At the end of the wheat cycle, samples of aerial weed and wheat biomass were taken from the plots. Aerial net primary productivity (NPPa), which includes total crop dry matter and total weed dry matter sampled at the end of the cycle. Grain yield, straw and husk biomass production, and weed biomass were determined in $0.5 \times 0.5 \mathrm{~m}$ squares randomly thrown at the center of each plot, following the simple random sampling (SRS) method. For wheat and weed biomass, plants inside the square were cut at ground level. Wheat plants were separated into spike and stem. Wheat and weed biomass were dried at $70^{\circ} \mathrm{C}$ to obtain dry weight. Fresh spikes were previously threshed to separate grain and grain husk. The ratio between weed biomass and NPPa (weed:NPPa ratio), i.e., the share of agroecosystem biomass allocated to weed, was also calculated.

Root biomass was sampled at post-anthesis for cultivars planted at Sierra de Yeguas, at the third year of the experiment (2016). Two soil cubes of $25 \times 25 \times 25 \mathrm{~cm}$ were extracted at the center of each plot, washed, and sieved ( $2 \mathrm{~mm}$ ) at farm-gate. At the laboratory, root biomass was washed, extracted, and estimated following Metcalfe et al. [38]. The extrapolated value of root biomass, on the basis of the logarithmic equation obtained through this method, increased by $20 \%$ and $17 \%$ the extracted root biomass of OV and MV, respectively. The R:S ratio was calculated as the ratio between root and aboveground wheat biomass dry matter.

\subsection{Modelling of NPP and Biomass Fluxes According to Their Destiny}

From wheat yield and cultivated area in each point in time, and from the information (HI, root: shoot ratio and weed biomass) obtained from trials, for OV, and the bibliographic review, for MV, we have modeled the impact of the varietal change on the NPP per hectare in wheat fields throughout the 20th century. Based on Pujol-Andreu [39] and Sánchez-García et al. [8], we have considered that until 1950, OV under traditional management represented 100\% of the cultivated area. From 1980, 
the same happens with MV under modern management. In the transition period, a progressive substitution of $50 \%$ for 1960 and $75 \%$ for 1970 has been considered (Table S5).

Subsequently, we have broken down the NPP into biomass flows according to their destination at each moment (Table S6).

\section{Results}

\subsection{Experimental Fields Results}

3.1.1. Net Primary Productivity (NPP) and Its Components of Both OV and MV under Organic Managements

Aerial Net Primary Productivity (NPPa) ranged from $1249 \mathrm{~kg} \mathrm{ha}^{-1}$ produced in old wheat plots in the one-third rotation in 2014 , to $11,807 \mathrm{~kg} \mathrm{ha}^{-1}$ of old wheat plots in the wheat-faba bean rotation in 2014 (Table 2).

In the wheat-faba bean rotation, plots cultivated with OV had significantly higher NPPa than those cultivated with MV in 2014 and 2016 (27\% and 17\% higher, respectively). Straw productivity was significantly higher for OV during the three growing seasons ( $62 \%, 31 \%$ and $30 \%$ higher, respectively). Husk productivity was significantly higher for OV only in 2014 ( $86 \%$ higher). While significant differences for grain yield were found in 2014 and 2015, with 79\% higher and 36\% lower yield for old wheat comparing it to the modern one, respectively. However, weed biomass was significantly higher in MV plots during the three growing seasons (53\%, 1233\% and 102\% higher, respectively). Regarding root biomass, OV produced significantly more biomass tan MV in 2016 (41\% higher), the only year in which root production was measured.

In the one-third rotation, OV plots had significantly higher NPPa than modern ones for the three years (40\%, 39\% and 22\% higher, respectively for 2014, 2015 and 2016). Straw productivity was also significantly higher for OV during the three growing seasons $(60 \%, 82 \%$ and $55 \%$, higher, respectively). Likewise, husk productivity was significantly higher for OV $(111 \%, 70 \%$, and $55 \%$ higher in 2014 , 2015 and 2016). Contrarily, significant differences for grain yield were only found in 2014, with a $67 \%$ higher yield for old wheat compared to the modern one. Regarding weed biomass, we only found significant differences in 2016, when plots cultivated with MV produced $34 \%$ higher weed biomass.

\subsubsection{Biomass Allocation and Partitioning Indices}

Biomass allocation has been proved to be different for OV and MV in both organic trials. Considering only aerial wheat biomass, the grain represented $22 \%$ to $26 \%$ of the NPPa in OV, and $30 \%$ to $35 \%$ in MV (for wheat-faba bean and one third rotations, respectively). In both cases, the increase is $35 \%$ in MV with respect to OV. In the wheat-faba bean rotation, if we take root biomass into account, the grain goes from representing $17 \%$ of the total wheat biomass in OV, to $24 \%$ in MV (39\% more for MV) (Figure 1a).

Considering the whole plot, that is, including weeds, the accumulation of aerial biomass in the grain of MV is still higher than that of OV. However, the increase is reduced to 25 and $22 \%$ (wheat-faba bean and one third rotations, respectively). In wheat-faba bean, if we include root biomass, the increase is reduced from $39 \%$ to $30 \%$ (Figure $1 \mathrm{~b}$ ). The reduction of the difference between varieties in biomass allocation to grain (whether accounting for root biomass or not) is due to the greater contribution of weeds to biomass of plots cultivated with MV, when comparing to OV. This indicates a lower capacity of MV to compete with weeds. 
Table 2. Aerial and total Net Primary Productivity (NPPa and NPP, respectively), grain yield, straw, and husk production, and weed biomass (kg ha ${ }^{-1}$, dry matter) of old and modern wheat varieties in wheat-faba bean rotation (W-FB R) and in one third rotation (O-T R) trials. Mean and standard error of the mean. Different letters represent significant differences between OV and MV within each growing season at a level of 0.05 (Tukey test).

\begin{tabular}{|c|c|c|c|c|c|c|c|c|c|}
\hline & & \multicolumn{2}{|c|}{2014} & \multicolumn{2}{|c|}{2015} & \multicolumn{2}{|c|}{2016} & \multicolumn{2}{|c|}{ Average } \\
\hline & & Old & Modern & Old & Modern & Old & Modern & Old & Modern \\
\hline \multirow{4}{*}{ W-FB R } & $\begin{array}{l}\text { NPPa } \\
\text { NPP }\end{array}$ & $11,807 \mathrm{a} \pm 581$ & $9292 b \pm 697$ & $11,570 \mathrm{a} \pm 428$ & $11,078 \mathrm{a} \pm 483$ & $\begin{array}{l}7000 a \pm 395 \\
9486 a \pm 395\end{array}$ & $\begin{array}{l}5957 b \pm 315 \\
7713 b \pm 315\end{array}$ & $10,126 \pm 377$ & $8776 \pm 389$ \\
\hline & Straw & $6186 a \pm 492$ & $3812 b \pm 312$ & $7767 a \pm 305$ & $5946 b \pm 288$ & $4967 a \pm 271$ & $3831 b \pm 189$ & $6307 \pm 250$ & $4530 \pm 194$ \\
\hline & $\begin{array}{l}\text { Husk } \\
\text { Root }\end{array}$ & $1014 a \pm 120$ & $544 b \pm 43$ & $1276 a \pm 63$ & $1126 a \pm 60$ & $\begin{array}{c}532 a \pm 52 \\
2486 a \pm \pm 252\end{array}$ & $\begin{array}{c}458 \mathrm{a} \pm 33 \\
1757 b=166\end{array}$ & $941 \pm 60$ & $709 \pm 44$ \\
\hline & Weed & $2421 b \pm 417$ & $3712 a \pm 609$ & $3 b \pm 2$ & $40 \mathrm{a} \pm 14$ & $126 \mathrm{~b} \pm 30$ & $254 \mathrm{a} \pm 50$ & $850 \pm 191$ & $1335 \pm 283$ \\
\hline \multirow{4}{*}{ O-T R } & Grain & $256 a \pm 45$ & $153 b \pm 36$ & $623 a \pm 58$ & $569 a \pm 46$ & $385 a \pm 47$ & $438 \mathrm{a} \pm 61$ & $421 \pm 34$ & $387 \pm 35$ \\
\hline & Straw & $597 a \pm 40$ & $374 b \pm 38$ & $1247 \mathrm{a} \pm 73$ & $684 b \pm 53$ & $1095 a \pm 77$ & $708 b \pm 51$ & $980 \pm 50$ & $589 \pm 33$ \\
\hline & Husk & $139 a \pm 29$ & $66 \mathrm{~b} \pm 19$ & $342 a \pm 28$ & $201 b \pm 14$ & $251 a \pm 21$ & $162 b \pm 15$ & $244 \pm 18$ & $143 \pm 11$ \\
\hline & Weed & $257 a \pm 35$ & $300 a \pm 36$ & $342 a \pm 41$ & $387 a \pm 44$ & $226 b \pm 24$ & $302 a \pm 33$ & $275 \pm 20$ & $330 \pm 22$ \\
\hline
\end{tabular}


Averaged weed biomass from both organic managements $\left(562 \mathrm{~kg} \mathrm{~d} . \mathrm{m} . \mathrm{ha}^{-1}\right)$ will be used in the modelling of NPP of OV under organic farming in Spanish wheat fields (Section 3.2).

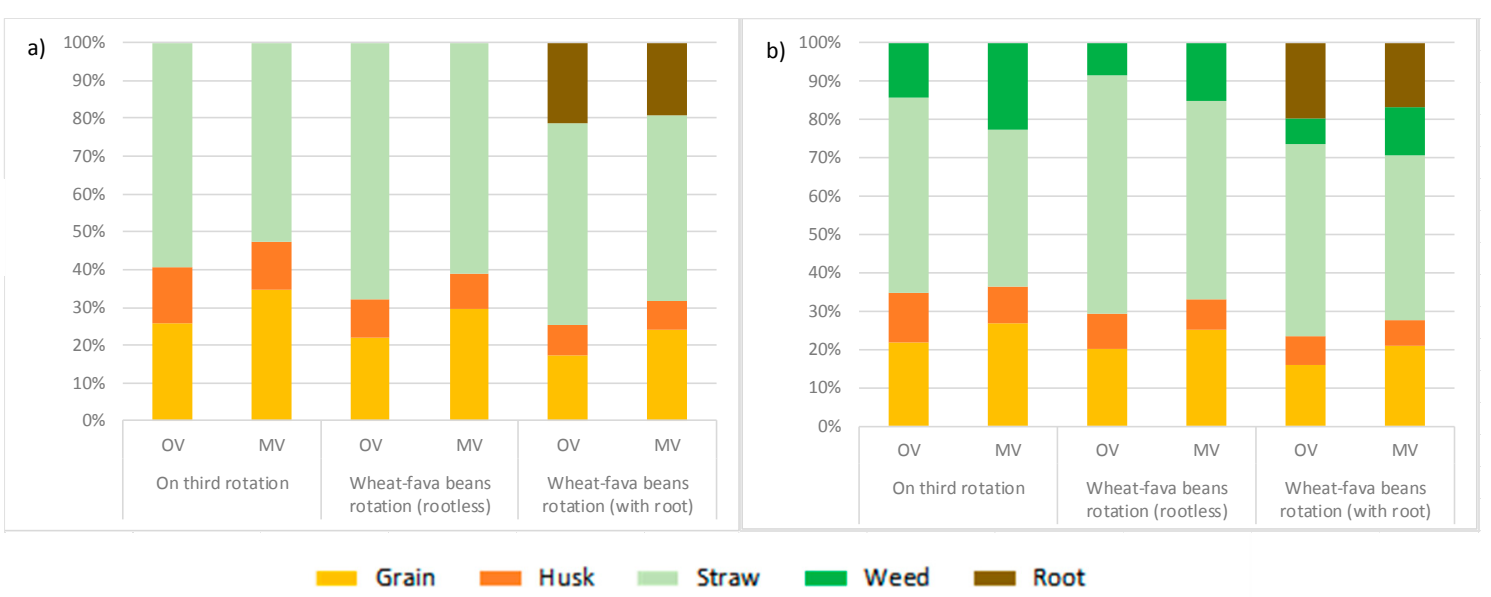

Figure 1. Biomass allocation of (a) wheat varieties (OV, old varieties; $M V$, modern varieties), and (b) net primary productivity of plots cultivated with OV and MV, under different management.

As a consequence of the different allocation of biomass, the partitioning indices vary between types of varieties and with management (Table 3). In the wheat-faba bean rotation, HI ranged $0.211-0.238$ and 0.206-0.393 for OV and MV, respectively. No significant differences were found in 2014 and 2016, while it was 39\% significantly lower for OV in 2015. Finally, OV had significantly lower Weed:NPPa ratio values than modern ones (44\%, 93\% and 55\% lower values in 2014, 2015 and 2016, respectively).

In the one-third rotation, $\mathrm{HI}$ ranged from $0.193-0.308$ and $0.219-0.389$ for OV and MV, respectively. The difference was significant in favor of MV in 2015 and 2016, with an increase of $26 \%$ and 49\%, respectively, with respect to OV. Lastly, OV plots showed a significantly lower Weed: NPPa ratio for 2014, 2015, and 2016 (44\%, 38\% and 37\% lower, respectively).

Mean HI of OV is similar under both organic managements $(0.228$ and 0.237 for the wheat-faba bean rotation and the one-third rotation, respectively), being the average of both (0.232) used in calculations of the NPP in Section 3.3. The intensity of the organic management does not seem to have affected the HI of MV either (0.287-0.298), being higher the influence of the growing season.

Lastly, the R:S ratio was 0.36 for OV in the wheat-faba bean rotation in 2016 (Table 2). 
Table 3. Harvest index (fresh matter) and Weed:NPPa ratio (aerial dry matter) of old (OV) and modern (MV) wheat varieties in wheat-faba bean rotation (W-FB R) and one third rotation (O-T R) trials. Mean and standard error of the mean. Different letters represent significant differences between OV and MV within each growing season at a level of 0.05 (Tukey test).

\begin{tabular}{cccccccccc}
\hline & & \multicolumn{2}{c}{$\mathbf{2 0 1 4}$} & \multicolumn{2}{c}{$\mathbf{2 0 1 5}$} & \multicolumn{2}{c}{ 2016 } & Average \\
\cline { 3 - 8 } & & OV & MV & OV & MV & OV & MV & OV & MV \\
\hline Harvest index & W-FB R & $0.235 \mathrm{a} \pm 0.021$ & $0.206 \mathrm{a} \pm 0.028$ & $0.238 \mathrm{~b} \pm 0.006$ & $0.393 \mathrm{a} \pm 0.011$ & $0.211 \mathrm{a} \pm 0.017$ & $0.262 \mathrm{a} \pm 0.020$ & $0.228 \pm 0.009$ & $0.287 \pm 0.015$ \\
& O-T R & $0.209 \mathrm{a} \pm 0.026$ & $0.219 \mathrm{a} \pm 0.037$ & $0.308 \mathrm{~b} \pm 0.013$ & $0.389 \mathrm{a} \pm 0.020$ & $0.193 \mathrm{~b} \pm 0.012$ & $0.287 \mathrm{a} \pm 0.023$ & $0.237 \pm 0.012$ & $0.298 \pm 0.018$ \\
\hline \multirow{2}{*}{ Weed:NPPa } & W-FB R & $0.210 \mathrm{~b} \pm 0.038$ & $0.371 \mathrm{a} \pm 0.041$ & $0.0003 \mathrm{~b} \pm 0.000$ & $0.004 \mathrm{a} \pm 0.002$ & $0.019 \mathrm{~b} \pm 0.004$ & $0.041 \mathrm{a} \pm 0.006$ & $0.076 \pm 0.017$ & $0.139 \pm 0.024$ \\
& O-T R & $0.195 \mathrm{~b} \pm 0.020$ & $0.358 \mathrm{a} \pm 0.042$ & $0.130 \mathrm{~b} \pm 0.011$ & $0.212 \mathrm{a} \pm 0.020$ & $0.124 \mathrm{~b} \pm 0.013$ & $0.194 \mathrm{a} \pm 0.022$ & $0.150 \pm 0.010$ & $0.255 \pm 0.019$ \\
\hline
\end{tabular}




\subsection{Total Wheat Production and Cultivated Area for Spanish Wheat Fields in the 20th Century}

The wheat area cultivated under rainfed conditions in Spain increased from 3.4 to 4.3 Mha in the first third of the 20th century (Figure 2). This trend was broken with the Spanish Civil War (1936-1939), which meant the loss of almost 1 Mha. From 1940, the surface recovered and reached 3.9 Mha in 1950. The next two decades show a great stability, but since the 80 s, the surface area falls sharply due to the abandonment of the less productive rainfed croplands [40] and the replacement of cereals by olives. After the entry of Spain into the European Union [40] many cereal drylands were abandoned due to the subsidies that the EU started to give through the common agrarian policies (CAP) to farmers who dedicated land to the production of olive oil.

Total grain production followed a similar trend until 1960. Varietal substitution with cultivars from foreign origin and other selected in Spanish research centers had begun with some entity in the 1950s. These varieties were, in general, long-stemmed, with some exceptions harboring Rht dwarfing alleles, such as Mara, Impeto or Estrella varieties [15,39]. These varieties, despite being long-stemmed, produced more grain than $\mathrm{OV}$, so their $\mathrm{HI}$ was higher than those of $\mathrm{OV}$ ( 0.40 on average according to Sánchez-García et al. [15]). Their presence in the Spanish fields was progressive, and contributed to the increase in yield (Figure 3) and total grain production in the 1960s and 1970s (Figure 2). But it was from the mid-70s that semidwarf varieties from CIMMYT were introduced, with varietal substitution being very rapid [8,39]. As a result, wheat yield doubled in the 1980s compared to 1950, and continued to grow until the year 2000 (Figure 3), so that, despite the drastic fall in area, total grain production grew to reach $5.2 \mathrm{Mt}$ (Figure 2).

Likewise, harvested residues followed a similar evolution than surface and grain production until 1970 (Figure 2). As of this date, they fell sharply due to the disappearance of traction animals and the intensification of animal husbandry in Spain, which relied on compound feed [40].

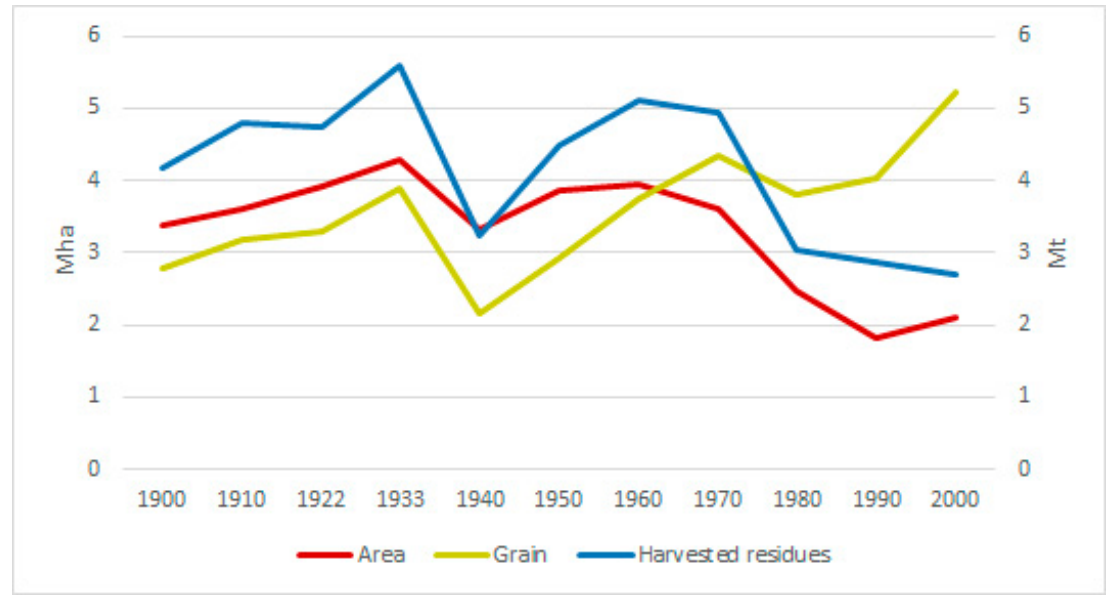

Figure 2. Evolution of the surface area (Mha), total grain production and harvested residues (Mt fresh matter) of wheat in Spain throughout the 20th century. Source: [16-21].

\subsection{Modelling of NPP and Biomass Destinies for Spanish Wheat Fields in the 20th Century}

On the basis of yield, we have calculated the NPP of wheat fields in the 20th century (Figure 3a). During the first third of the century, the average wheat yield remained fairly stable, with a slight upward trend (it rose from $725 \mathrm{~kg} \mathrm{d.m.} \mathrm{ha}{ }^{-1}$ in 1900 to $796 \mathrm{~kg} \mathrm{d.m.} \mathrm{ha}{ }^{-1}$ in 1933), derived from a slight degree of rotations intensification and the incipient use of fertilizers [37]. The different NPP components reflect this stability, since neither the cultivated genetic material nor the weed control technology were altered. In the 1940s, the yield loss associated with the Spanish Civil War would also be reflected in aboveground wheat residues (Figure 3b) and NPP (Figure 3a), but foreseeably not in the rest of the components. As we explained in the methodology section, the R:S ratio tends to decrease under conditions of higher fertilizer and water use intensity, conditions that did not 
occur here. Weed biomass should not have changed significantly either, since the capacity of OV to maintain weeds in relatively low populations remained unchanged. If so, it could have increased slightly, especially in 1940, due to the difficulties of carrying out the manual weeding work traditionally practiced. Between 1960 and 1980, from the beginning and end of the varietal replacement process, wheat yield increased by $62 \%$. However, NPP did not exceed that of 1933 , because the moderate increase in yield and the higher weed biomass under modern management did not compensate for the reduction of root and stem biomass due to the incorporation of the new varieties. Finally, we identify a last period (1990-2000) in which the NPP in wheat fields exceeded what was reached in the first third of the century (Figure 3a). In this period, the yield increase (160\% with respect to 1960) and the biomass associated with this increase did compensate for the relative reduction in residue production. In 1990, for the first time, the residues produced exceeded those of the first third of the century (Figure 3b).
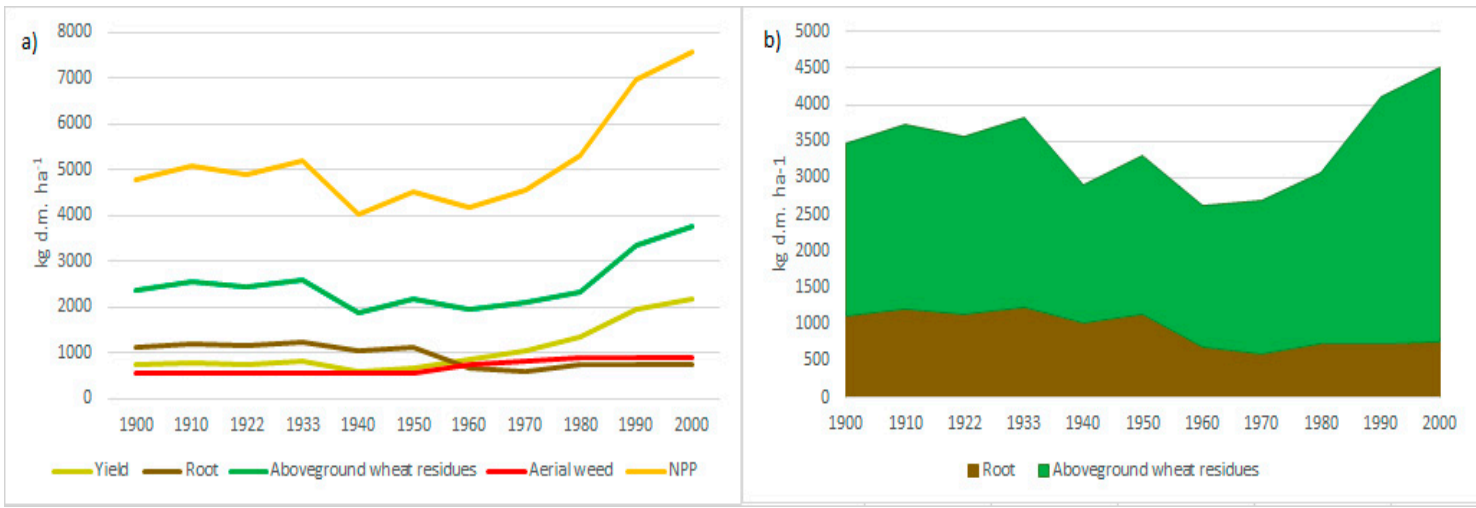

Figure 3. Evolution of (a) Net Primary Productivity (NPP) of wheat fields and (b) of wheat residues, in Spain throughout the 20th century.

Given that a part of the residues produced was extracted from the agroecosystem for animal feed, we must disaggregate it by use in order to quantify the residue biomass actually available to maintain the biophysical quality of the agroecosystems and allocate it above or below ground. The residues harvested for use by livestock have remained fairly stable in absolute terms (Figure 4a). However, in relative terms, the residue harvest increased during the 1960-70 period (Figure 4b), due to the fall in total residue production caused by the varietal replacement (Figure 4a). Subsequently, the relative extraction was reduced by the increase in residue production due to the yield increase (Figure 4 b). Initially, this residue overproduction is partially burned by farmers, until legal restrictions were imposed [41] (Figure 4b). Given the stability of the straw biomass extracted per hectare, the aboveground unharvested biomass (AUhB) evolves following the trend of the aerial biomass (Figures $3 \mathrm{~b}$ and $4 \mathrm{c}$ ). The slight increase in the first third of the century is interrupted, first by the armed conflict and, subsequently (1960-70), by the fall in the residue production due to varietal replacement. In 1980, aerial residue production was recovered at the 1933 level, if we consider weed biomass (Figure 4c), and it was surpassed in 1990-2000 due to the significant increase in residue production and the stability of consumption by livestock. If weed biomass is not considered (Figure $4 \mathrm{~d}$ ), the recovery of the AUhB is delayed, and it does not reach the previous records until 1990. Nevertheless, the belowground unharvested biomass (BUhB) falls and does not recover, once the varietal change occurs (Figure 4c,d). The impact of unharvested biomass (UhB) changes on fund elements (soil and biodiversity) are discussed in the following section. 

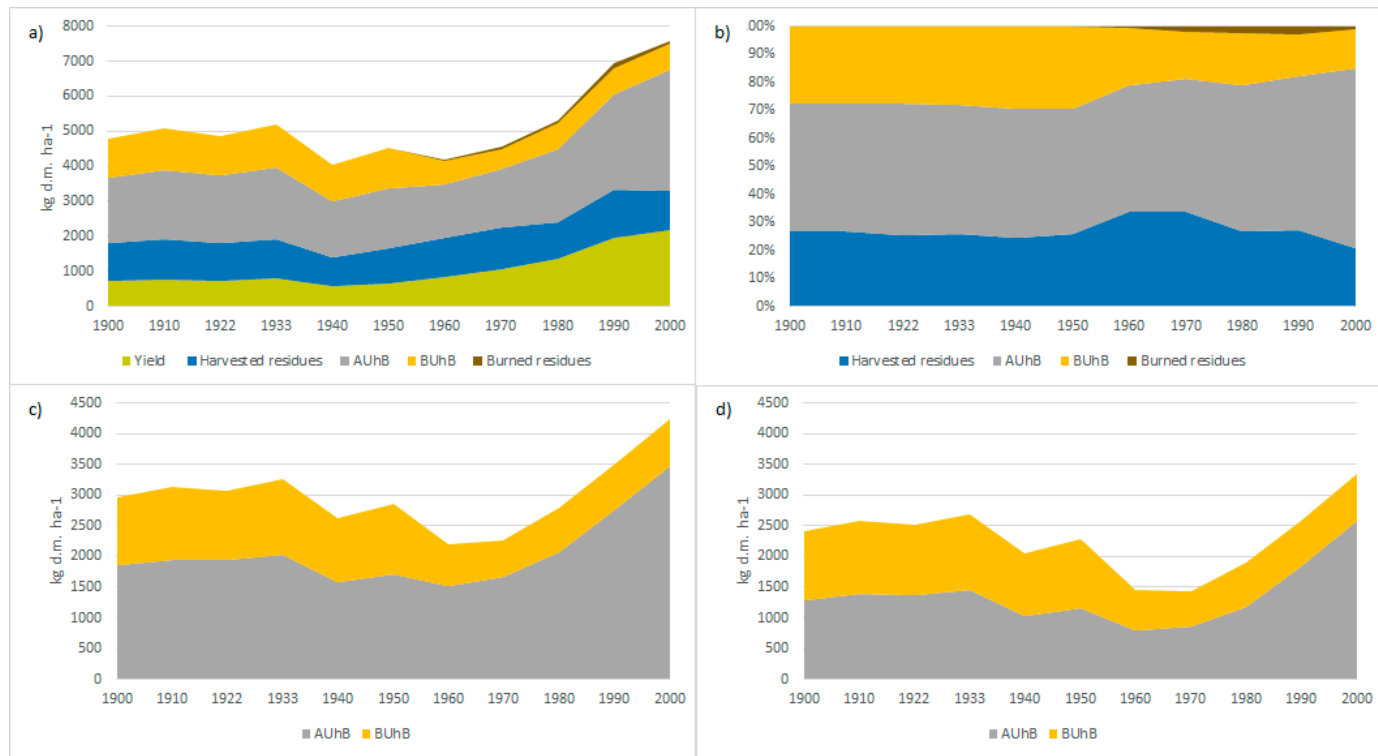

Figure 4. Reconstruction of biomass destinations (kg d.m. ha ${ }^{-1}$ ) of Spanish wheat fields (1900-2000), (a) of NPP, including aerial weed biomass, (b) of residue production in relative terms, aerial weed biomass included, (c) of unharvested residues, aerial weed included, (d) of unharvested residues, weed biomass excluded. (AUhB: Aboveground Unharvested Biomass, BUhB: Belowground Unharvested Biomass).

\section{Discussion}

\subsection{Comparison of Old and Modern Varieties Under Two Traditional Organic Managements}

Results from the trials show that OV are more productive than MV under those management conditions in which the former were selected, that is, they produce more biomass than modern ones. And this was true for both trials, whose grain yield differences were similar to those found in the historical data of both rotations $[18,19,42]$. That is, under rainfed conditions in semi-arid regions and with organic management, MV do not compensate for the loss of straw production with the increase in grain. On the contrary, MV decreased aerial biomass production in $68 \%$ in one third rotation and $80 \%$ in wheat-faba bean rotation, when compared to OV. Therefore, there is a net reduction in the productivity of wheat aerial biomass with MV, which gets higher with tighter agroclimatic limitations. Results obtained in the most intensive organic management are similar to those found under Mediterranean dryland conditions under industrialized management, in which Giambalvo et al. [43] found reductions of $13-22 \%$ in the NPPa of MV with respect to OV. Carranza-Gallego et al. [44] found 17\%. Annicchiarico et al. [45] and Motzo et al. [46] found 9\% lower biomass for MV than that of OV.

In terms of grain yield, there are almost no differences between types of variety. However, differences can be found depending on the organic management intensity and soil conditions. The inclusion of the legume in the rotation and the application of manure multiplied by more than five times the yield of wheat. In Ronda, the coarse soil texture surely limited water retention and SOM accumulation, which probably contributed to the low yield observed. On the other hand, averaged grain yield ( $421 \mathrm{~kg} \mathrm{d.m.} \mathrm{ha}{ }^{-1}$ for OV and $387 \mathrm{~kg} \mathrm{d.m.} \mathrm{ha}{ }^{-1}$ for MV) in the one-third rotation is similar to the average yield of conventionally managed wheat in the most arid provinces of Southeastern Spain (Murcia, Almería, Alicante), during the same years of the trials [17], with average rainfall lower than $350 \mathrm{~mm}$. The average grain yield in the wheat-faba bean rotation $\left(2028 \mathrm{~kg} \mathrm{~d} . \mathrm{m} . \mathrm{ha}^{-1}\right.$ for OV and $2201 \mathrm{~kg} \mathrm{d.m.} \mathrm{ha}{ }^{-1}$ for MV) is slightly higher than that of conventionally managed wheat in a rainfed regime in the province of Málaga, where both trials are located, for the years of the study $\left(1753 \mathrm{~kg}\right.$ f.m. ha $\left.{ }^{-1}\right)$ [17]. Higher rainfall during the second growing season in Sierra de Yeguas could 
have been responsible of the higher yield of MV in 2015, as rainfall is a major factor determining the grain yield of wheat cultivated under rainfed conditions [47]. Additionally, the lower weed biomass of this growing season could have helped MV to produce more grain, as they are not a good competitor against weed. The yield obtained both for OV and MV is within the normal range for the region with industrialized management, in relatively dry years (Table 1). This is probably due to the fact that, under these agroclimatic conditions, increases in grain productivity due to the increase of external inputs are not very relevant, or even nonexistent [48,49]. Specifically, the application of nitrogen fertilizer does not necessarily contribute to higher yields under stressful conditions [50].

The higher root biomass of OV agrees with that obtained in other field trials in the Mediterranean environment [23]. Lopes et al. [51] state that Mediterranean wheat landraces are adapted to low input farming systems and present traits related to drought and heat stress. For instance, their higher root systems might perform higher soil water uptake in deep soil layers [52], allowing for a better adaptation to rainfed conditions. On the other hand, the higher root development of Mediterranean landraces can foster $\mathrm{N}$ uptake efficiency [53], as it makes them more capable of recovering soil $\mathrm{N}$ from deeper soil than modern cultivars [54]. Higher root biomass would also contribute to a higher accumulation of organic matter in the soil [43], since root biomass is more efficient than aerial biomass for this purpose [55,56]. More SOM increases the water holding capacity of the soil [57] and, thus, water availability for the crop which, under Mediterranean rainfed conditions, implies a higher NPP, including grain. On the other hand, Junaidi et al. [58] show that there is a genotype $\times$ environment interaction in relation to root size, and suggest that genotypes with the highest R:S ratios also have the greatest increase in root and aboveground biomass when they are organically fertilized. This suggests that organic management could stimulate root growth in OV, and reinforces the need for further trials under the conditions in which these varieties were generated and not, as usual, under industrialized management conditions.

The weed biomass of plots cultivated with MV is higher in both trials. This result is expected, since wheat improvement is based on the Donald's ideotype, which is a phenotype with low intra and interspecific competitive ability, but with great capacity to produce more seeds. That is, the increase in wheat grain yield is associated with a reduced competitive ability against weeds [59-61]. Plants have different mechanisms to compete with other plants. One of them is the production of higher vegetative biomass, which occupies space and subtracts resources (water, light, nutrients) for the rest. Another mechanism is allelopathy, which negatively affects the germination and growth of other plants. Both mechanisms are present in the OV included in this study [62]. The allelopathic capacity of cereal crops could have been lost in modern cultivars due to breeding programs [63]. Therefore, the assumption of Donald's ideotype as a model for the design of wheat MV involved the loss of their ability to compete with weeds by their own means, relying on the intensive use of tillage and/or herbicides to perform this function. Differences in weed biomass between the first growing season and the other ones in Sierra de Yeguas could be due to the crop rotation sequence, since faba bean can have a suppressive effect on weeds [64] and its morphology and in row planting pattern make its weeding very effective. Finally, the precedent uncompetitive crops or a deficient mechanical weed management in the farmland previous to the experiment establishment could have also enhanced the weed population in the first year.

\subsection{Evolution of NPP of Wheat Fields in Spain throughout the 20th Century}

The NPP evolution in Spanish wheat fields is complex, as technological and social factors intermingle and have an impact on it. Our results show that the Spanish Civil War and agriculture policies from the first decades of the Franco dictatorship had a relevant impact on the production, not only of grain, but also of aerial residues. The reduction in the availability of human and animal work, as well as the interruption of the incipient importation of fertilizers, mainly phosphorus, was behind this fall [37]. The lower availability of residues probably initiated a process of deterioration of the fund elements and environmental services of these agroecosystems, as we will discuss in Section 4.3. 
This decrease in NPP may have been temporary. However, it was prolonged over time due to the biological change that led to the introduction of varieties with "Reduced Height Genes" (Rht) from CIMMYT in the 70-80s. The average increases in grain yield obtained were far from those documented in other European regions with higher rainfall $[39,65]$. The drop in residue production did not generate, in principle, any detectable problem in the short term. On the one hand, straw had lost functionality due to the substitution of labor animals by automotive machinery. On the other hand, in the incipient stages of agrarian mechanization, shorter varieties should have greatly facilitated the harvest. The limited capacity of the harvesters lengthened the collection period and facilitated the lodging of OV, with the consequent losses of grain quantity and quality. In addition, lodging risk limited the possibility of increasing fertilizer doses. Therefore, this biological innovation was, in general, well received [39].

Finally, at the end of the 20th century (1990-2000), the upturn in yield observed enabled it to overcome the residue production of $\mathrm{OV}$ of the first third of the century. This increase in yield has a complex explanation, which we can only venture. We do not have reliable data on the inputs applied to wheat in this period. Total consumption for Spanish agriculture shows a slight upward trend in the period 1980-2000 [40]. A slight increase (12\%) of nitrogen fertilizer applied to wheat between 1990 and 2000 is considered from the calculation of nitrous oxide emissions by Spanish inventory of emissions to the atmosphere [66]. Given the lack of response to mineral nitrogen supply under water stress conditions, the increase in $\mathrm{N}$ fertilizer application and the associated response, has possibly been parallel to the shift of the cultivation of rainfed wheat to areas with higher rainfall and the abandonment in more arid regions. To prove this, in Figure 5 we have represented the provinces that have increased or reduced their representativeness in cultivated surface of rainfed wheat since 1980. Between 1980 and 1990, four provinces (Cádiz, Sevilla, Burgos, and Navarra) increased more than 1\% their wheat surface in relation to the national surface (Figure 5a). Together, they went from representing $19.6 \%$ of the national surface of rainfed wheat to $25.5 \%$. At the other extreme, the other four provinces (Cáceres, Valladolid, Huesca and Teruel) reduced their representativeness by more than $1 \%$ and, overall, went from representing $10.8 \%$ of the national surface of rainfed wheat to $6.0 \%$ (Figure $5 \mathrm{a}$ ). The average pluviometry of the former reaches $735 \pm 133 \mathrm{~mm}$ year $^{-1}$, compared to $592 \pm 135 \mathrm{~mm}$ year ${ }^{-1}$ of the latter. Following the same trend, provinces that gained between 0.3 and $1 \%$ of representativeness have an average rainfall of $637 \pm 127 \mathrm{~mm}_{\text {year }}{ }^{-1}$ compared to $543 \pm 91 \mathrm{~mm}$ year $^{-1}$ of the provinces that lost between $0.3-1 \%$ of representativeness [67]. Between 1980-2000 (Figure 5b), the trend is the same: concentration of rainfed wheat cultivation in more humid provinces and abandonment in drier ones. Therefore, this increase in residue in recent decades does not contradict our hypothesis, but rather reinforces it, since the abandonment in more arid provinces may be related to the degradation of the fund elements of the agroecosystem caused by the decrease in unharvested residues. We will address this in Section 4.3.

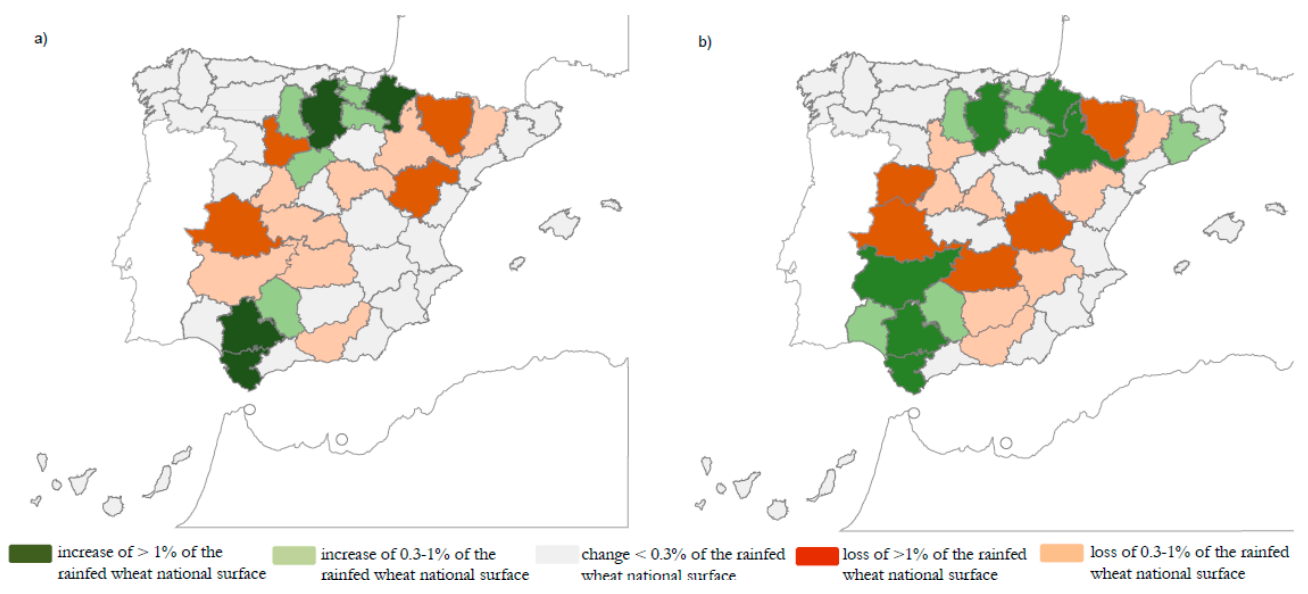

Figure 5. Evolution of the distribution of the surface of rainfed wheat in Spanish provinces. (a) 1980-1990; (b) 1980-2000. 


\subsection{Impact on the Fund Elements and Environmental Services of Spanish Wheat Fields}

The varietal substitution had unforeseen consequences on the quality of the biophysical fund elements (soil and biodiversity) of cereal-based agroecosystems and, consequently, on the ecosystem services they provide.

Several studies show the low level of soil organic carbon (SOC) in cereal Spanish drylands at present [68,69], which is very close to the degradation threshold [69]. Crop management, and particularly varietal choices, are important drivers of SOC levels, which change in response to soil C inputs [70,71]. It has been estimated that average SOC levels in Spanish rainfed croplands have been continuously decreasing since 1940 due to decreasing C inputs to the soil and, in the last decades, to global warming [41]. In the case of cereals, this fall in soil C inputs was mainly due to varietal change. The depletion of these soils is an important vulnerability factor for the sustainability of Mediterranean agriculture in a context of climate change [72]. Organic matter does not only constitute a store of nutrients, but also of water, at the same time that it controls the common erosive processes under Mediterranean conditions. Therefore, the decrease of AUhB and, mainly, of BUhB, ends up triggering complex processes of degradation that undermine the productive capacity of these soils and promote their abandonment. In Spain, 2.5 Mha of rainfed agricultural land (12\% of cropland) were abandoned since the mid-1980s to the year 2000 due to its low productivity. $88 \%$ of this land was previously dedicated to extensive crops (cereal and legumes, mainly) and fallow [17]. The abandonment affected mainly those rotations that were less intensive, which manifested into a fallow abandonment annual rate of $2.4 \%$ against the $0.8 \%$ for cultivated land. This situation would be in line with the displacement of wheat crop to provinces with higher rainfall as we have shown in this article. Therefore, the increase in average yields of rainfed wheat between 1980-2000 cannot be strictly attributed to varietal change. The higher quality of lands dedicated to wheat at the end of the century compared to previous decades would have enabled a higher production intensification, raising the average yield.

The recovery of degraded soils requires the implementation of uses and managements that leave more unharvested residues on the soil $[68,69,73]$. According to our results, OV could contribute to this, without reducing grain yield.

The decrease in UhB could also have seriously affected biodiversity. If we consider bird species threatened in Spain as an indicator of biodiversity, $17.5 \%$ of them are associated with cereal, and 5\% to agricultural spaces with high diversity (vegetable gardens, irrigated orchards, etc.) ([74] p. 80). Cereal does not constitute a group of crops especially intensive in the use of fertilizers and pesticides under Mediterranean rainfed conditions. However, UhB debacle reaches extremes in cereals. The scarce production of straw from modern varieties, mostly of short size and short cycle, and the burning of stubble, make these crops scarcely useable for heterotrophic species, which affects the size of the populations that can maintain them and trophic chains of which they are part. This is the case of populations of predatory birds, such as the lesser kestrel (Falco naumanni), whose decline is linked to the need to invest a much greater effort to obtain their prey (arthropods and small vertebrates) in cereal fields as they have been modernized [75]. AUhB also offers food and shelter for the reproduction of other birds linked to cereal fields. Hence, part of the recommended actions in the framework of the Life Project for the conservation of steppe birds proposed by the Consejería de Medio Ambiente de Andalucía [76] is to use varieties with a longer cycle and more straw than current ones. That is, varieties more similar to traditional ones. The application of herbicides also produces damage to biodiversity, both flora and fauna [77-80], which would be avoided with the cultivation of OV.

As a result of the varietal change and the related intensification in inputs use, the sustainability of wheat fields has been undermined and its recovery is not viable if it is not through the production of biomass at low cost and without competing with those uses of biomass that generate income for the farmer [81]. Therefore, the evaluation of varietal suitability can not only be based on the capacity to produce more marketable biomass, but also on the size of the non-harvested portion, which recirculates through the agroecosystem. 
In the light of these results, it would be of great interest to obtain data from long-term experiments, with different varieties and in other pedo-climatic situations under Mediterranean and other semi-arid climates, so that we could corroborate the hypothesis presented here. Additionally, the study of the economic viability of old and modern wheat varieties cultivation under both organic and conventional management in Mediterranean drylands could also be accomplished.

\section{Conclusions}

The idea that wheat MV are more productive than OV is based on a double bias. The first is produced by considering a part (grain) as the whole (NPP), thus neglecting the functions of residues in maintaining the productive capacity of agroecosystems. The second bias is produced by generalizing the reach of results mostly obtained under industrialized management, which clearly benefits MV, to other contexts. However, both trials carried out here show that, under Mediterranean rainfed conditions and traditional organic management, biomass production of OV is significantly higher than that of MV. This is due to a higher straw and root biomass production, without significantly decreasing yield. Different biomass allocation of varieties results in a lower $\mathrm{HI}$ and a higher R:S ratio for OV. However, weed biomass is higher in plots planted with MV, due to the loss of competitive capacity that accompanied the selection for grain yield.

Combining information obtained from trials for OV with traditional organic management, bibliographic review for MV under industrialized management, and information from historical sources, we have reconstructed the NPP (and the uses of the different portions) of Spanish wheat fields throughout the 20th century. Results show a strong decline of NPP and UhB during wars in the 1940s-1950s, which lasted over time and was exacerbated by the progressive replacement of OV from the 1960s, a process that accelerated in the 1970-1980s by the rapid introduction of "Rht" varieties from CIMMYT. The fall of UhB has meant less biomass available to maintain the levels of organic matter in the soil and to sustaining food chains of heterotrophic species, leading to the degradation of rainfed cereal agroecosystems. The massive abandonment of these degraded agroecosystems and the displacement of the wheat crop towards provinces with more rainfall have increase the yield and NPP of this crop at the end of the century.

The results obtained suggest that OV under organic management can increase the sustainability of rainfed Mediterranean agroecosystems at present. Specifically, they can improve soil quality, increase carbon sequestration in the soil, reduce the need for agrochemicals, especially herbicides, and promote the recovery of biodiversity. All without significant decreases in grain production under organic management.

Supplementary Materials: The following are available online at http://www.mdpi.com/2071-1050/10/10/ 3724/s1. Table S1: Harvest Index of modern varieties cultivated in rainfed Mediterranean environment under industrialized management, Table S2: Weed biomass of modern varieties under industrialized management, Table S3: Share of burned residues for wheat (1900-2000), Table S4: Field trials soil physic-chemical proprieties, Table S5: Evolution of Net Primary Productivity and partitioning indices, Table S6: Reconstruction of biomass destinations of Spanish wheat fields (1900-2000). References [82-127] are cited in Supplementary Materials.

Author Contributions: Conceptualization, G.I.G.; Data curation, G.C.-G. and G.I.G.; Formal analysis, G.C.-G. and G.I.G.; Funding acquisition, M.G.d.M.; Investigation, G.C.-G. and G.I.G.; Methodology, G.C.-G. and G.I.G.; Project administration, M.G.d.M.; Resources, G.C.-G., G.I.G., D.S., E.A., I.V., J.I.-A., A.H. and M.G.d.M.; Supervision, G.C.-G., G.I.G., D.S., E.A., I.V., J.I.-A., A.H. and M.G.d.M.; Validation, G.C.-G. and G.I.G.; Visualization, G.C.-G., G.I.G., D.S., E.A., I.V., J.I.-A., A.H. and M.G.d.M.; Writing—original draft, G.C.-G. and G.I.G.; Writing一review \& editing, G.C.-G., G.I.G., D.S. and E.A.

Funding: Funding was provided by the international research project SSHRC 895-2011-1020 granted by the Social Sciences and Humanities Research Council of Canada, and the Spanish research projects HAR2012-38920-C02-01 and HAR2015-69620-C2-1-P granted by the Spanish Ministry of Economy and Competitiveness. The first authoress held a FPU scholarship from the Spanish Government.

Conflicts of Interest: The authors declare no conflict of interest. The funders had no role in the design of the study; in the collection, analyses, or interpretation of data; in the writing of the manuscript, or in the decision to publish the results. 


\section{References}

1. Borlaug, N.; Dowsell, C. The green revolution: An unfinished agenda. In Proceedings of the Lecture to Food and Agriculture Organization, Committee on World Food Security, 30th Session, Rome, Italy, 20-23 September 2004; Available online: www.fao.org/docrep/meeting/008/J3205e/j3205e00.html (accessed on 24 August 2018).

2. Kloppenburg, J.R. First the Seed: The Political Economy of Plant Biotechnology; University of Wisconsin Press: Madison, WI, USA, 2005; p. 468. ISBN 029919244X.

3. Pingali, P.; Raney, T. From the green revolution to the gene revolution: How will the poor fare? Mansholt Publ. Ser. 2005, 4, 407.

4. FAO (Food and Agriculture Organization). FAOSTAT, 2018. Available online: http://www.fao.org/faostat/ es/\#home (accessed on 29 June 2018).

5. Austin, R.B.; Bingham, J.; Blackwell, R.D.; Evans, L.T.; Ford, M.A.; Morgan, C.L.; Taylor, M. Genetic improvements in winter-wheat yields since 1900 and associated physiological-changes. J. Agric. Sci. 1980, 94, 675-689. [CrossRef]

6. De Vita, P.; Nicosia, O.L.D.; Nigro, F.; Platani, C.; Riefolo, C.; Di Fonzo, N.; Cattivelli, L. Breeding progress in morpho-physiological, agronomical and qualitative traits of durum wheat cultivars released in Italy during the 20th century. Eur. J. Agron. 2007, 26, 39-53. [CrossRef]

7. Guarda, G.; Padovan, S.; Delogu, G. Grain yield, nitrogen-use efficiency and baking quality of old and modern Italian bread-wheat cultivars grown at different nitrogen levels. Eur. J. Agron. 2004, 21, 181-192. [CrossRef]

8. Sánchez-Garcia, M. Genetic Gains and Changes in the Pattern of Adaptation of Bread Wheat Varieties Grown in Spain during the 20th Century. Ph.D. Thesis, Universitat de Lleida and IRTA, 2013. Available online: http:/ / hdl.handle.net/10803/109262 (accessed on 15 June 2018).

9. Gliessman, S.R. Field and Laboratory Investigations in Agroecology: A Manual to Accompany Agroecology: Ecological Processes in Sustainable Agriculture; Ann Arbor Press: Ann Arbor, MI, USA, 1998; p. 330, ISBN-10: 1-56670-445-6.

10. Guzmán, G.I.; González de Molina, M. Energy in Agroecosystems: A Tool for Assessing Sustainability; CRC Press: Boca Raton, FL, USA, 2017.

11. Guzman, G.I.; Aguilera, E.; Garcia-Ruiz, R.; Torremocha, E.; Soto-Fernandez, D.; Infante-Amate, J.; Gonzalez de Molina, M. The agrarian metabolism as a tool for assessing agrarian sustainability, and its application to Spanish agriculture (1960-2008). Ecol. Soc. 2018, 23. [CrossRef]

12. Ho, M.-W. Circular thermodynamics of organisms and sustainable systems. Systems 2013, 1, 30-49. [CrossRef]

13. Ho, M.-W.; Ulanowicz, R. Sustainable systems as organisms? Biosystems 2005, 82, 39-51. [CrossRef] [PubMed]

14. Lo Valvo, P.J.; Miralles, D.J.; Serrago, R.A. Genetic progress in Argentine bread wheat varieties released between 1918 and 2011: Changes in physiological and numerical yield components. Field Crops Res. 2017, 221, 314-321. [CrossRef]

15. Sanchez-Garcia, M.; Alvaro, F.; Peremarti, A.; Trevaskis, B.; Martin-Sanchez, J.A.; Royo, C. Breeding effects on dry matter accumulation and partitioning in Spanish bread wheat during the 20th century. Euphytica 2015, 203, 321-336. [CrossRef]

16. GEHR. Estadísticas históricas de la producción agraria española, 1859-1935; Ministerio de Agricultura, Pesca y Alimentación: Madrid, Spain, 1991.

17. MAPAMA (Ministerio de Agricultura y Pesca, Alimentación y Medio Ambiente). Anuario de Estadística. 2018. Available online: https:/ / www.mapama.gob.es/es/estadistica/temas/publicaciones/anuario-deestadistica/ (accessed on 12 July 2018).

18. JCA (Junta Consultiva Agronómica). Avance estadístico sobre el cultivo cereal y de leguminosas asociadas en España formado por la Junta Consultiva Agronómica, 1890, quinquenio de 1886 a 1890 ambos inclusive; Dirección General de Agricultura, Industria y Comercio, Tipografía de L. Peant e hijos: Madrid, Spain, 1891.

19. JCA (Junta Consultiva Agronómica). Noticias estadísticas sobre la producción agrícola española por la Junta Consultiva Agronómica, 1902; Dirección General de Agricultura, Imprenta Alemana: Madrid, Spain, 1903. 
20. JCA (Junta Consultiva Agronómica). Avance estadístico de la riqueza que en España representa la producción media anual en el decenio de 1903 a 1912 de cereales y leguminosas, vid y olivo y aprovechamientos diversos derivados de estos cultivos; Resumen hecho por la Junta Consultiva Agronómica de las memorias de 1913, remitidas por los ingenieros del servicio agronómico provincial, Madrid; Ministerio de Fomento, Dirección General de Agricultura, Minas y Montes: Madrid, Spain, 1913.

21. JCA (Junta Consultiva Agronómica). Avance estadístico de la producción agrícola en España. Resumen hecho por la Junta Consultiva Agronómica de las memorias de 1922; Remitidas por los ingenieros del servicio agronómico provincial, Madrid; Ministerio de Fomento, Dirección General de Agricultura, Minas y Montes. Imprenta de los hijos de M.G. Hernández: Madrid, Spain, 1923.

22. Bektas, H.; Hohn, C.E.; Waines, J.G. Root and shoot traits of bread wheat (Triticum aestivum L.) landraces and cultivars. Euphytica 2016, 212, 297-311. [CrossRef]

23. Siddique, K.H.M.; Belford, R.K.; Tennant, D. Root-shoot ratios of old and modern, tall and semidwarf wheats in a mediterranean environment. Plant Soil 1990, 121, 89-98. [CrossRef]

24. Subira, J.; Ammar, K.; Álvaro, F.; Del Moral, L.F.G.; Dreisigacker, S.; Royo, C. Changes in durum wheat root and aerial biomass caused by the introduction of the Rht-B1b dwarfing allele and their effects on yield formation. Plant Soil 2016, 403, 291-304. [CrossRef]

25. Lynch, J.; Marschner, P.; Rengel, Z. Effect of Internal and External Factors on Root Growth and Development. In Marschner's Mineral Nutrition of Higher Plants, 3rd ed.; Marschner, H., Ed.; Academic Press: Waltham, MA, USA, 2012; pp. 331-346.

26. Hilbert, D.W.; Canadell, J. Biomass partitioning and resource allocation of plants from Mediterranean-type ecosystems: Possible responses to elevated atmospheric $\mathrm{CO}_{2}$. In Global Change and Mediterranean-Type Ecosystems; Moreno, J.M., Oechel, W.C., Eds.; Springer: New York, NY, USA, 1995; pp. 76-101, ISBN 978-1-4612-8690-5.

27. Hu, T.; Sorensen, P.; Wahlstrom, E.M.; Chirinda, N.; Sharif, B.; Li, X.; Olesen, J.E. Root biomass in cereals, catch crops and weeds can be reliably estimated without considering aboveground biomass. Agric. Ecosyst. Environ. 2018, 251, 141-148. [CrossRef]

28. Andrews, M.; Raven, J.A.; Sprent, J.I. Environmental effects on dry matter partitioning between shoot and root of crop plants: Relations with growth and shoot protein concentration. Ann. Appl. Biol. 2001, 138, 57-68. [CrossRef]

29. Chirinda, N.; Olesen, J.E.; Porter, J.R. Root carbon input in organic and inorganic fertilizer-based systems. Plant Soil 2012, 359, 321-333. [CrossRef]

30. Gan, Y.T.; Campbell, C.A.; Janzen, H.H.; Lemke, R.L.; Basnyat, P.; McDonald, C.L. Carbon input to soil from oilseed and pulse crops on the Canadian prairies. Agric. Ecosyst. Environ. 2009, 132, 290-297. [CrossRef]

31. Taghizadeh-Toosi, A.; Christensen, B.T.; Glendining, M.; Olesen, J.E. Consolidating soil carbon turnover models by improved estimates of belowground carbon input. Sci. Rep. 2016, 6. [CrossRef] [PubMed]

32. Wiesmeier, M.; Huebner, R.; Dechow, R.; Maier, H.; Spoerlein, P.; Geuss, U.; Hangen, E.; Reischl, A.; Schilling, B.; von Luetzow, M.; et al. Estimation of past and recent carbon input by crops into agricultural soils of southeast Germany. Eur. J. Agron. 2014, 61, 10-23. [CrossRef]

33. Muñoz-Romero, V.; Benítez-Vega, J.; López-Bellido, R.J.; Fontán, J.M.; López-Bellido, L. Effect of tillage system on the root growth of spring wheat. Plant Soil 2010, 326, 97-107. [CrossRef]

34. Olmo, M.; Antonio Alburquerque, J.; Barron, V.; Carmen del Campillo, M.; Gallardo, A.; Fuentes, M.; Villar, R. Wheat growth and yield responses to biochar addition under Mediterranean climate conditions. Biol. Fertil. Soils 2014, 50, 1177-1187. [CrossRef]

35. Plaza-Bonilla, D.; Alvaro-Fuentes, J.; Hansen, N.C.; Lampurlanes, J.; Cantero-Martinez, C. Winter cereal root growth and aboveground-belowground biomass ratios as affected by site and tillage system in dryland Mediterranean conditions. Plant Soil 2014, 374, 925-939. [CrossRef]

36. Carranza-Gallego, G.; Guzmán, G.I.; García-Ruíz, R.; González de Molina, M.; Aguilera, E. Addressing the role of old wheat varieties in the sustainability of Mediterranean rainfed agroecosystems. forthcoming.

37. Soto, D.; Infante-Amate, J.; Guzmán, G.I.; Cid, A.; Aguilera, E.; García-Ruiz, R.; González de Molina, M. The social metabolism of biomass in Spain, 1900-2008: From food to feed-oriented changes in the agro-ecosystems. Ecol. Econ. 2016, 128, 130-138. [CrossRef] 
38. Metcalfe, D.B.; Williams, M.; Aragão, L.; Da Costa, A.C.L.; De Almeida, S.S.; Braga, A.P.; Gonçalves, P.H.L.; De Athaydes, J.; Junior, S.; Malhi, Y. A method for extracting plant roots from soil which facilitates rapid sample processing without compromising measurement accuracy. New Phytol. 2007, 174, 697-703. [CrossRef] [PubMed]

39. Pujol-Andreu, J. Nuevas perspectivas en historia económica: Innovaciones biológicas y cambio técnico en el sector triguero europeo, siglos XIX-XX. Sociedad Española de Historia Agraria-Documento de Trabajo: 11-03. 2011, p. 42. Available online: http:/ / repositori.uji.es/xmlui/bitstream/handle/10234/21036/DT\%2011-03.pdf (accessed on 3 July 2018).

40. González de Molina, M.; Soto, D.; Infante-Amate, J.; Aguilera, E.; Vila-Traver, J.; Guzmán, G.I. Decoupling food from land: The evolution of Spanish agriculture from 1960 to 2010. Sustainability 2017, 9, 2348. [CrossRef]

41. Aguilera, E.; Guzmán, G.I.; Álvaro-Fuentes, J.; Infante-Amate, J.; García-Ruiz, R.; Carranza-Gallego, G.; Soto, D.; de Molina, M.G. A historical perspective on soil organic carbon in Mediterranean cropland (Spain, 1900-2008). Sci. Total Environ. 2018, 621, 634-648. [CrossRef] [PubMed]

42. González de Molina, M.; Guzmán Casado, G.I.; García Ruíz, R.; Soto Fernández, D.; Herrera, A.; Infante Amate, J. Claves del crecimiento agrario: La reposición de la fertilidad en la agricultura andaluza de los siglos XVIII y XIX. In La reposición de la fertilidad en los sistemas agrarios tradicionales; Garrabou Segura, R., González de Molina, M., Eds.; Icaria: Barcelona, Spain, 2010; pp. 127-170. ISBN 978-84-9888-215-5.

43. Giambalvo, D.; Ruisi, P.; Di Miceli, G.; Frenda, A.S.; Amato, G. Nitrogen use efficiency and nitrogen fertilizer recovery of durum wheat genotypes as affected by interspecific competition. Agron. J. 2010, 102, 707-715. [CrossRef]

44. Carranza-Gallego, G.; Guzman, G.I.; Garcia-Ruiz, R.; Gonzalez de Molina, M.; Aguilera, E. Contribution of old wheat varieties to climate change mitigation under contrasting managements and rainfed Mediterranean conditions. J. Clean. Prod. 2018, 195, 111-121. [CrossRef]

45. Annicchiarico, P.; Abdellaoui, Z.; Kelkouli, M.; Zerargui, H. Grain yield, straw yield and economic value of tall and semi-dwarf durum wheat cultivars in Algeria. J. Agric. Sci. 2005, 143, 57-64. [CrossRef]

46. Motzo, R.; Fois, S.; Giunta, F. Relationship between grain yield and quality of durum wheats from different eras of breeding. Euphytica 2004, 140, 147-154. [CrossRef]

47. Ayadi, S.; Karmous, C.; Chamekh, Z.; Hammami, Z.; Baraket, M.; Esposito, S.; Rezgui, S.; Trifa, Y. Effects of nitrogen rates on grain yield and nitrogen agronomic efficiency of durum wheat genotypes under different environments. Ann. Appl. Biol. 2016, 168, 264-273. [CrossRef]

48. Angás, P.; Lampurlanés, J.; Cantero-Martínez, C. Tillage and N fertilization: Effects on N dynamics and barley yield under semiarid Mediterranean conditions. Soil Tillage Res. 2006, 87, 59-71. [CrossRef]

49. Lacasta, C. Agricultura ecológica en cereales de secano; Conserjería de Agricultura y Pesca, Ed.; Junta de Andalucía: Seville, Spain, 2007.

50. Ferrante, A.; Cartelle, J.; Savin, R.; Slafer, G.A. Yield determination, interplay between major components and yield stability in a traditional and a contemporary wheat across a wide range of environments. Field Crops Res. 2017, 203, 114-127. [CrossRef]

51. Lopes, M.S.; El-Basyoni, I.; Baenziger, P.S.; Singh, S.; Royo, C.; Ozbek, K.; Aktas, H.; Ozer, E.; Ozdemir, F.; Manickavelu, A.; et al. Exploiting genetic diversity from landraces in wheat breeding for adaptation to climate change. J. Exp. Bot. 2015, 66, 3477-3486. [CrossRef] [PubMed]

52. Annicchiarico, P.; Pecetti, L. Developing a tall durum wheat plant type for semi-arid, Mediterranean cereal-livestock farming systems. Field Crops Res. 2003, 80, 157-164. [CrossRef]

53. Baresel, J.P.; Reents, H.J.; Zimmermann, G. Field evaluation criteria for nitrogen uptake and nitrogen use efficiency. In Proceedings of the COST SUSVAR/ECO-PB Workshop on Organic Plant Breeding Strategies and the Use of Molecular Markers, Driebergen, The Netherlands, 17-19 January 2005; p. 49.

54. Foulkes, M.J.; Sylvester-Bradley, R.; Scott, R.K. Evidence for differences between winter wheat cultivars in acquisition of soil mineral nitrogen and uptake and utilization of applied fertilizer nitrogen. J. Agric. Sci. 1998, 130, 29-44. [CrossRef]

55. Rasse, D.P.; Rumpel, C.; Dignac, M.F. Is soil carbon mostly root carbon? Mechanisms for a specific stabilisation. Plant Soil 2005, 269, 341-356. [CrossRef]

56. Kätterer, T.; Bolinder, M.A.; Andrén, O.; Kirchmann, H.; Menichetti, L. Roots contribute more to refractory soil organic matter than above-ground crop residues, as revealed by a long-term field experiment. Agric. Ecosyst. Environ. 2001, 141, 184-192. [CrossRef] 
57. Diacono, M.; Montemurro, F. Long-term effects of organic amendments on soil fertility. A review. Agron. Sustain. Dev. 2010, 30, 401-422. [CrossRef]

58. Junaidi, J.; Kallenbach, C.M.; Byrne, P.F.; Fonte, S.J. Root traits and root biomass allocation impact how wheat genotypes respond to organic amendments and earthworms. PLoS ONE 2018, 13. [CrossRef] [PubMed]

59. Reynolds, M.P.; Acevedo, E.; Sayre, K.D.; Fischer, R.A. Yield potential in modern wheat varieties: Its association with a less competitive ideotype. Field Crops Res. 1994, 37, 149-160. [CrossRef]

60. Sadras, V.O.; Lawson, C. Genetic gain in yield and associated changes in phenotype, trait plasticity and competitive ability of South Australian wheat varieties released between 1958 and 2007. Crop Pasture Sci. 2011, 62, 533-549. [CrossRef]

61. Sukumaran, S.; Reynolds, M.P.; Lopes, M.S.; Crossa, J. Genome-Wide Association Study for Adaptation to Agronomic Plant Density: A Component of High Yield Potential in Spring Wheat. Crop Sci. 2015, 55, 2609-2619. [CrossRef]

62. Pedrol, N.; Carranza-Gallego, G.; Canabal, A.; Guzmán, G.I. Allelopathic ability of old and modern wheat varieties under organic rainfed Mediterranean conditions. A filed and laboratory test. forthcoming.

63. Bertholdsson, N.O. Variation in allelopathic activity over 100 years of barley selection and breeding. Weed Res. 2004, 44, 78-86. [CrossRef]

64. Álvarez-Iglesias, L.; Puig, C.G.; Garabatos, A.; Reigosa, M.J.; Pedrol, N. Vicia faba aqueous extracts and plant material can suppress weeds and enhance crops. Allelopath. J. 2014, 34, 299-314.

65. Borojevic, K.; Borojevic, K. The transfer and history of "reduced height genes" (Rht) in wheat from Japan to Europe. J. Hered. 2005, 96, 455-459. [CrossRef] [PubMed]

66. MAGRAMA (Ministerio de Agricultura, Pesca y Medio Ambiente). Inventario de emisiones de gases de efecto invernadero de España 1990-2010; Ministerio de Medio Ambiente, Medio Rural y Marino: Madrid, Spain, 2012.

67. AEMET (Agencia Estatal de Meteorología). Visor del atlas climático de la Península y Baleares. 2018. Available online: http:/ / www.aemet.es/es/serviciosclimaticos/datosclimatologicos/atlas_climatico/visor_ atlas_climatico (accessed 14 August 2018).

68. Rodriguez Martin, J.A.; Alvaro-Fuentes, J.; Gonzalo, J.; Gil, C.; Ramos-Miras, J.J.; Corbi, J.M.G.; Boluda, R. Assessment of the soil organic carbon stock in Spain. Geoderma 2016, 264, 117-125. [CrossRef]

69. Romanyá, J.A.; Rovira, P.; Vallejo, R. Análisis del carbono en los suelos agrícolas de España. Aspectos relevantes en relación a la reconversión a la agricultura ecológica en el ámbito mediterráneo. Rev. Ecosistemas 2007, 16, 50-57.

70. Paustian, K.; Six, J.; Elliott, E.T.; Hunt, H.W. Management options for reducing $\mathrm{CO}_{2}$ emissions from agricultural soils. Biogeochemistry 2000, 48, 147-163. [CrossRef]

71. Aguilera, E.; Lassaletta, L.; Gattinger, A.; Gimeno, B.S. Managing soil carbon for climate change mitigation and adaptation in Mediterranean cropping systems: A meta-analysis. Agric. Ecosyst. Environ. 2013, 168, 25-36. [CrossRef]

72. Iglesias, A.; Mougou, R.; Moneo, M.; Quiroga, S. Towards adaptation of agriculture to climate change in the Mediterranean. Reg. Environ. Chang. 2011, 11, 159-166. [CrossRef]

73. Segura, C.; Jimenez, M.N.; Nieto, O.; Navarro, F.B.; Fernandez-Ondono, E. Changes in soil organic carbon over 20 years after afforestation in semiarid SE Spain. For. Ecol. Manag. 2016, 381, 268-278. [CrossRef]

74. EEME (Evaluación de los Ecosistemas del Milenio de España). La Evaluación de los Ecosistemas del Milenio de España. Sintesis de resultados. Fundación Biodiversidad; Ministerio de Medio Ambiente, y Medio Rural y Marino: Madrid, Spain, 2011.

75. Consejería de Medio Ambiente. Factores limitantes para las poblaciones. In El cernícalo primilla en Andalucía. Bases ecológicas para su conservación. Manuales de conservación de la naturaleza, $n^{\circ} 2$ '; Fernández-Palacios, J.M. (Coord), Ed.; Consejería de Medio Ambiente, Junta de Andalucía: Sevilla, Spain, 2004; pp. 56-73. Available online: www.juntadeandalucia.es/medioambiente/web/Bloques_Tematicos/Estado_Y_Calidad_De_Los_ Recursos_Naturales/Fauna/Cernicalo_primilla/cap3.pdf (accessed on 1 October 2017).

76. Consejería de Medio Ambiente. Actuaciones del proyecto LIFE Esteparias. 2003. Available online: http://www.juntadeandalucia.es/medioambiente/site/portalweb/menuitem. 7e1cf46ddf59bb227a9ebe205510e1ca/?vgnextoid=feb3855b92a3a210VgnVCM1000001325e50aRCRD\& vgnextchannel=1d6df3378dea5310VgnVCM2000000624e50aRCRD\&lr=lang_es\&vgnsecondoid= 3664855b92a3a210VgnVCM1000001325e50a___ \&param1=1 (accessed on 10 October 2017). 
77. Freemark, K.; Boutin, C. Impacts of agricultural herbicide use on terrestrial wildlife in temperate landscapes-A review with special reference to North-America. Agric. Ecosyst. Environ. 1995, 52, 67-91. [CrossRef]

78. José-María, L.; Sans, F.X. Weed seedbanks in arable fields: Effects of management practices and surrounding landscape. Weed Res. 2011, 51, 631-640. [CrossRef]

79. Marshall, E.J.P.; Brown, V.K.; Boatman, N.D.; Lutman, P.J.W.; Squire, G.R.; Ward, L.K. The role of weeds in supporting biological diversity within crop fields. Weed Res. 2003, 43, 77-89. [CrossRef]

80. Pimentel, D.; Acquay, H.; Biltonen, M.; Rice, P.; Silva, M.; Nelson, J.; Lipner, S.; Giordano, S.; Horowitz, A.; D'amore, M. Environmental and economic costs of pesticide use. BioScience 1992, 42, 750-760. [CrossRef]

81. Tittonell, P.; Scopel, E.; Andrieu, N.; Posthumus, H.; Mapfumo, P.; Corbeels, M.; van Halsema, G.E.; Lahmar, R.; Lugandu, S.; Rakotoarisoa, J.; et al. Agroecology-based aggradation-conservation agriculture (ABACO): Targeting innovations to combat soil degradation and food insecurity in semi-arid Africa. Field Crops Res. 2012, 132, 168-174. [CrossRef]

82. Albrizio, R.; Todorovic, M.; Matic, T.; Stellacci, A.M. Comparing the interactive effects of water and nitrogen on durum wheat and barley grown in a Mediterranean environment. Field Crops Res. 2010, 115, 179-190. [CrossRef]

83. Al-Ghzawi, A.L.A.; Khalaf, Y.B.; Al-Ajlouni, Z.I.; Al-Quraan, N.A.; Musallam, I.; Hani, N.B. The Effect of Supplemental Irrigation on Canopy Temperature Depression, Chlorophyll Content, and Water Use Efficiency in Three Wheat (Triticum aestivum L. and T. durum Desf.) Varieties Grown in Dry Regions of Jordan. Agric.-Basel 2018, 8. [CrossRef]

84. Ali, S.A.; Tedone, L.; Verdini, L.; De Mastro, G. Effect of different crop management systems on rainfed durum wheat greenhouse gas emissions and carbon footprint under Mediterranean conditions. J. Clean. Prod. 2017, 140, 608-621. [CrossRef]

85. Apesteguia, M.; Virto, I.; Orcaray, L.; Enrique, A.; Bescansa, P. Effect of the Conversion to Irrigation of Semiarid Mediterranean Dryland Agrosecoystems on Soil Carbon Dynamics and Soil Aggregation. Arid Land Res. Manag. 2015, 29, 399-414. [CrossRef]

86. Arduini, I.; Masoni, A.; Ercoli, L.; Mariotti, M. Grain yield, and dry matter and nitrogen accumulation and remobilization in durum wheat as affected by variety and seeding rate. Eur. J. Agron. 2006, 25, 309-318. [CrossRef]

87. Arenas-Corraliza, M.G.; López-Díaz, M.L.; Moreno, G. Winter cereal production in a Mediterranean silvoarable walnut system in the face of climate change. Agric. Ecosys. Environ. 2018, 264, 111-118. [CrossRef]

88. Bort, J.; Fraj, M.B.; Latiri, K.; Kehel, Z.; Araus, J.L. Comparative performance of the stable isotope signatures of carbon, nitrogen and oxygen in assessing early vigour and grain yield in durum wheat-CORRIGENDUM. J. Agric. Sci. 2014, 152, 408-426. [CrossRef]

89. Bouthiba, A.; Debaeke, P.; Hamoudi, S.A. Varietal differences in the response of durum wheat (Triticum turgidum L. var. durum) to irrigation strategies in a semi-arid region of Algeria. Irrig. Sci. 2008, 26, 239-251. [CrossRef]

90. Campiglia, E.; Mancinelli, R.; De Stefanis, E.; Pucciarmati, S.; Radicetti, E. The long-term effects of conventional and organic cropping systems, tillage managements and weather conditions on yield and grain quality of durum wheat (Triticum durum Desf.) in the Mediterranean environment of Central Italy. Field Crops Res. 2015, 176, 34-44. [CrossRef]

91. Celik, S.K.; Madenoglu, S.; Sonmez, B.; Avag, K.; Turker, U.; Cayci, G.; Kutuk, C.; Heng, L. Assessment of effects of different irrigation water regime on winter wheat yield and water use efficiency. Sci. Pap. Ser. E Land Reclam. Earth Observ. Surv. Environ. Eng. 2017, 6, 93-97.

92. Dalias, P. Increased yield surplus of vetch-wheat rotations under drought in a mediterranean environment. Sci. World J. 2012, 2012, 658518. [CrossRef] [PubMed]

93. Diacono, M.; Castrignano, A.; Troccoli, A.; De Benedetto, D.; Basso, B.; Rubino, P. Spatial and temporal variability of wheat grain yield and quality in a Mediterranean environment: A multivariate geostatistical approach. Field Crops Res. 2012, 131, 49-62. [CrossRef]

94. Ercoli, L.; Lulli, L.; Mariotti, M.; Masoni, A.; Arduini, I. Post-anthesis dry matter and nitrogen dynamics in durum wheat as affected by nitrogen supply and soil water availability. Eur. J. Agron. 2008, 28, 138-147. [CrossRef] 
95. Ercoli, L.; Lulli, L.; Arduini, I.; Mariotti, M.; Masoni, A. Durum wheat grain yield and quality as affected by S rate under Mediterranean conditions. Eur. J. Agron. 2011, 35, 63-70. [CrossRef]

96. Fagnano, M.; Fiorentino, N.; D’Egidio, M.G.; Quaranta, F.; Ritieni, A.; Ferracane, R.; Raimondi, G. Durum wheat in conventional and organic farming: Yield amount and pasta quality in Southern Italy. Sci. World J. 2012. [CrossRef] [PubMed]

97. French, R.J.; Schultz, J.E. Water use efficiency of wheat in a Mediterranean-type environment. I. The relation between yield, water use and climate. Aust. J. Agric. Res. 1984, 35, 743-764. [CrossRef]

98. García-Martín, A.; López-Bellido, R.J.; Coleto, J.M. Fertilisation and weed control effects on yield and weeds in durum wheat grown under rain-fed conditions in a Mediterranean climate. Weed Res. 2007, 47, 140-148. [CrossRef]

99. Gregory, P.J.; Tennant, D.; Belford, R.K. Root and shoot growth, and water and light use efficiency of barley and wheat crops grown on a shallow duplex soil in a Mediterranean-type environment. Aust. J. Agric. Res. 1992, 43, 555-573. [CrossRef]

100. Jahangir, K.; Saifullah, K.; Munir Ahmad Khetran, A.; Sadiq, N.; Islam, M.; Hanan, A.; Aziz, A. Tijaban-10 a drought tolerant and high yielding wheat variety for rainfed/sailaba areas of Balochistan. Pak. J. Bot. 2013, 45, 1357-1362.

101. Karam, F.; Kabalan, R.; Breidi, J.; Rouphael, Y.; Oweis, T. Yield and water-production functions of two durum wheat cultivars grown under different irrigation and nitrogen regimes. Agric. Water Manag. 2009, 96, $603-615$. [CrossRef]

102. Kobata, T.; Koç, M.; Barutçular, C.; Tanno, K.-I.; Inagaki, M. Harvest index is a critical factor influencing the grain yield of diverse wheat species under rain-fed conditions in the Mediterranean zone of southeastern Turkey and northern Syria. Plant Prod. Sci. 2018, 21, 71-82. [CrossRef]

103. Koç, M.; Barutçular, C.; Genç, I. Photosynthesis and productivity of old and modern durum wheats in a Mediterranean environment. Crop Sci. 2003, 43, 2089-2098. [CrossRef]

104. López-Bellido, L.; López-Bellido, R.J.; Redondo, R. Nitrogen efficiency in wheat under rainfed Mediterranean conditions as affected by split nitrogen application. Field Crops Res. 2005, 94, 86-97. [CrossRef]

105. López-Bellido, L.; López-Bellido, R.J.; Redondo, R.; Benítez, J. Faba bean nitrogen fixation in a wheat-based rotation under rainfed Mediterranean conditions: Effect of tillage system. Field Crops Res. 2006, 98, 253-260. [CrossRef]

106. Mansouri, A.; Oudjehih, B.; Benbelkacem, A.; Fellahi, Z.E.A.; Bouzerzour, H. Variation and Relationships among Agronomic Traits in Durum Wheat [Triticum turgidum (L.) Thell. ssp. turgidum conv. durum (Desf.) MacKey] under South Mediterranean Growth Conditions: Stepwise and Path Analyses. Int. J. Agron. 2018, 2018, 8191749. [CrossRef]

107. Mladenov, N.; Hristov, N.; Kondic-Spika, A.; Djuric, V.; Jevtic, R.; Mladenov, V. Breeding progress in grain yield of winter wheat cultivars grown at different nitrogen levels in semiarid conditions. Breed. Sci. 2011, 61, 260-268. [CrossRef]

108. Olgun, M.; Aygün, C. Evaluation of yield and yield components by different statistical methods in wheat (T. aestivum L.). CEP 2011, 88, 900.

109. Perry, M.W.; d'Antuono, M.F. Yield improvement and associated characteristics of some Australian spring wheat cultivars introduced between 1860 and 1982. Aust. J. Agric. Res. 1989, 40, 457-472.

110. Richards, R.A.; Rebetzke, G.J.; Condon, A.G.; Van Herwaarden, A.F. Breeding opportunities for increasing the efficiency of water use and crop yield in temperate cereals. Crop Sci. 2002, 42, 111-121. [CrossRef] [PubMed]

111. Ruisi, P.; Frangipane, B.; Amato, G.; Frenda, A.S.; Plaia, A.; Giambalvo, D.; Saia, S. Nitrogen uptake and nitrogen fertilizer recovery in old and modern wheat genotypes grown in the presence or absence of interspecific competition. Front. Plant Sci. 2015, 6, 185. [CrossRef] [PubMed]

112. Siddique, K.H.M.; Kirby, E.J.M.; Perry, M.W. Ear: Stem ratio in old and modern wheat varieties; relationship with improvement in number of grains per ear and yield. Field Crops Res. 1989, 21, 59-78. [CrossRef]

113. Siddique, K.H.M.; Belford, R.K.; Perry, M.W.; Tennant, D. Growth, development and light interception of old and modern wheat cultivars in a Mediterranean-type environment. Aust. J. Agric. Res. 1989, 40, 473-487.

114. Soriano, J.M.; Villegas, D.; Aranzana, M.J.; del Moral, L.F.G.; Royo, C. Genetic structure of modern durum wheat cultivars and mediterranean landraces matches with their agronomic performance. PLoS ONE 2016, 11, e0160983. [CrossRef] [PubMed] 
115. Tabatabaeefar, A.; Emamzadeh, H.; Varnamkhasti, M.G.; Rahimizadeh, R.; Karimi, M. Comparison of energy of tillage systems in wheat production. Energy 2009, 34, 41-45. [CrossRef]

116. Taner, A.; Arisoy, R.Z.; Kaya, Y.; Gultekin, I.; Partigoc, F. The effects of various tillage systems on grain yield, quality parameters and energy indices in winter wheat production under the rainfed conditions. Fresenius Environ. Bull. 2015, 24, 1463-1473.

117. Tedone, L.; Ali, S.A.; Verdini, L.; De Mastro, G. Nitrogen management strategy for optimizing agronomic and environmental performance of rainfed durum wheat under Mediterranean climate. J. Clean Prod. 2018, 172, 2058-2074. [CrossRef]

118. Tekin, S.; Yazar, A.; Barut, H. Comparison of wheat-based rotation systems and monocropping systems under dryland Mediterranean conditions. Int. J. Agric. Biol. Eng. 2017, 10, 203-213. [CrossRef]

119. Unkovich, M.; Baldock, J.; Forbes, M. Variability in harvest index of grain crops and potential significance for carbon accounting: Examples from Australian agriculture. In Advances in Agronomy; Elsevier: Amsterdam, The Netherlands, 2010; Volume 105, pp. 173-219.

120. van den Boogaard, R.; Veneklaas, E.J.; Peacock, J.M.; Lambers, H. Yield and water use of wheat (Triticum aestivum) in a Mediterranean environment: Cultivar differences and sowing density effects. Plant Soil 1996, 181, 251-262. [CrossRef]

121. Vergara-Diaz, O.; Kefauver, S.C.; Elazab, A.; Nieto-Taladriz, M.T.; Araus, J.L. Grain yield losses in yellow-rusted durum wheat estimated using digital and conventional parameters under field conditions. Crop J. 2015, 3, 200-210. [CrossRef]

122. Zhang, H.; Oweis, T.Y.; Garabet, S.; Pala, M. Water-use efficiency and transpiration efficiency of wheat under rain-fed conditions and supplemental irrigation in a Mediterranean-type environment. Plant Soil 1998, 201, 295-305. [CrossRef]

123. Borger, C.P.D.; Hashem, A.; Pathan, S. Manipulating crop row orientation to suppress weeds and increase crop yield. Weed Sci. 2010, 58, 174-178. [CrossRef]

124. Campiglia, E.; Radicetti, E.; Mancinelli, R. Floristic composition and species diversity of weed community after 10 years of different cropping systems and soil tillage in a Mediterranean environment. Weed Res. 2018. [CrossRef]

125. Mas, M.T.; Verdú, A.M.C. Tillage system effects on weed communities in a 4-year crop rotation under Mediterranean dryland conditions. Soil Tillage Res. 2003, 74, 15-24. [CrossRef]

126. Pardo, G.; Cirujeda, A.; Aibar, J.; Cavero Campo, J.; Zaragoza Larios, C. Weed harrowing in winter cereal under semi-arid conditions. Span. J. Agric. Res. 2008, 6. [CrossRef]

127. Togay, N.; Tepe, I.; Togay, Y.; Cig, F. Nitrogen levels and application methods affect weed biomass, yield and yield components in Tir'wheat (Triticum aestivum). N. Z. J. Crop Hortic. Sci. 2009, 37, 105-111. [CrossRef] 